\title{
Die Tomasevangelie: Inleidende opmerkings
}

Ernest van Eck

Tydelik-deeltydse dosent: Departement Nuwe-Testamentiese Wetenskap (Afd A)

Universiteit van Pretoria

\begin{abstract}
The Gospel of Thomas: Introductory remarks

The aim of this article is to present to South-African theologians, ministers and believers, in fairly popular fashion, the current debate in regard to some aspects of the non-canonical Gospel of Thomas. Attention is given to the discovery, text and publication of the Gospel of Thomas, the question of its dependence on or independence from the Synoptic gospels, the possible date of the Gospel, as well as to its theology (being either gnostic or non-gnostic). Finally, a few remarks in regard to the value of the studying of the Gospel of Thomas, in terms of theological debates in the church, are made.
\end{abstract}

Die doel van hierdie artikel is om, in hoofsaaklik populêre vorm, die jongste stand van navorsing rakende sekere aspekte van die nie-kanonieke Tomasevangelie (= EvTom) aan Suid-Afrikaanse teoloë, en in die besonder predikante en lidmate van die Nederduitsch Hervormde Kerk, bekend te stel. Die rede vir hierdie doel is tweeledig van aard: eerstens is dit haas onmoontlik om dit wat gedurende die afgelope vyftig jaar oor die EvTom gepubliseer is, binne 'n afsienbare tyd in terme van primêre bronne deur te werk $^{1}$. Daarom is daar in die onderhawige artikel meestal met sekondêre literatuur gewerk.

Die tweede rede hoekom daar gekies is vir bogenoemde doel, het te make met die feit dat hierdie artikel opgedra word aan prof $\mathrm{J} J$ Engelbrecht, emeritus hoogleraar in die Departement Bybelkunde, Universiteit van Pretoria. Prof Engelbrecht het, gedurende die afgelope sestien jaar wat die skrywer met hom bevriend is, deurgaans die gedagte uitgespreek dat teologiebeoefening altyd op die kerk gerig moet wees. Daarom het hy gepleit vir eenvoud, sonder om die skerp kante van enige teologiese kwessie of debat te probeer vermy. Waarvoor hy dus gepleit het, was om die soms baie moeilike teologiese debat oor verskeie sake in die Nuwe Testament so neer te pen dat dit nie alleen eenvoudig verstaanbaar is nie, maar bo alles, dat die kerk daarby kan baat. My hoop is dat die onderhawige artikel uitdrukking sal gee aan sy behoefte tot eenvoud en duidelikheid. 


\section{DIE ONTDEKKING, TEKS EN PUBLISERING VAN DIE TOMASEVAN- GELIE}

Die EvTom is in 1945 deur 'n Egiptiese boer genaamd Muhammed 'Ali al-Samman in bo-Egipte by Jabal al-Tabal ('n berggebied omring deur ongeveer 150 grotte) naby die dorpie Nag Hammadi, ontdek. Op soek na neerslae stikstofryke grond om in sy lande te strooi, het hy en sy seun op 'n erdekruik afgekom wat na nadere ondersoek as inhoud gehad het 13 kodekse gebind in leer bestaande uit meer as 50 individuele manuskripte geskryf op papirus' ${ }^{2}$. Alhoewel Muhammed 'Ali onmiddellik besef het dat sy ontdekking miskien waarde kon hê op die oudhede mark in bo-Egipte, het hy nie besef dat wat hy gevind het, heel waarskynlik die grootse argeologiese fonds in die geskiedenis van die Nuwe-Testamentiese wetenskap en die studie van die vroeë Christendom was nie (Kloppenborg et al 1990:81).

Die waarde van 'Ali se vonds het drie jaar later aan die lig gekom toe 'n Franse wetenskaplike en handelaar in oudhede, Jean Doresse, ' $n$ inventaris van die traktate (waarvan baie 'n duidelike gnostiese oriëntasie getoon het) van die 13 kodekse opgestel het $^{3}$. In Kodeks II (soos dit nou bekend staan) het Doresse 'n traktaat gevind (die tweede in Kodeks II) wat eindig met die woorde Peuaggelion Pkata Thomas. Wat hy gevind het, was 'n teks wat amper vir twee duisend jaar verlore was, naamlik die EvTom, geskryf in Kopties 4 .

Die interessante is egter dat die EvTom in wese reeds vroeër as 1945 'ontdek' is, en wel in $1897^{5}$. In hierdie jaar het twee Britse wetenskaplikes, te wete Grenfell en Hunt 'n klein papirusvel (ongeveer 14,5 x 9,5 cm) naby El Bahnasa, te Oxyrhynchus in Egipte, ontdek bestaande uit 7 Jesus-logia. Hulle het dit gepubliseer as Papirus Oxyrhynchus 1 (= P Oxy 1; kyk Grenfell \& Hunt 1897) ${ }^{6}$. In 1904 het hulle twee verdere manuskripte gepubliseer, te wete P Oxy 654 ('n enkele fragment van 'n papirusrol), en P Oxy 655 ('n paar fragmente van 'n ander rol; kyk Grenfell \& Hunt 1904). Volgens hulle interpretasie, op sowel ortografiese as paleografiese gronde, was $\mathrm{P}$ Oxy 1 nie later as 200 n C geskryf nie en P Oxy 654 en P Oxy 655 teen ongeveer 300 n C. Belangrik hier is dat bogenoemde drie fragmente, afleibaar op grond van hulle ortografie, van drie verskillende Griekse dokumente stam. Die feit dat P Oxy 1 van 'n papiruskodeks afkomstig is, en $P$ Oxy 655 van 'n papirusrol, dui verder daarop dat hierdie fragmente gedeeltes van literêre werke was. Drie verskillende Griekse tekste dui ook daarop dat die EvTom redelik gereeld in die derde eeu oorgeskryf is (kyk Fallon \& Cameron 1988:4201).

Een van die eerste moontlikhede wat met die ontdekking van die Koptiese teks van Tomas geopen is, was dat dit nou moontlik geword om bogenoemde drie manskripte te identifiseer. In 1952 het Puech raakgesien dat P Oxy 1, P Oxy 654 en P Oxy 655 frag 
mente van die Griekse teks van Tomas was. P Oxy 654 kom ooreen met die proloog en logia 1 tot 7 van die Tomasevangelie (= EvTom P en EvTom 1-7), P Oxy 1 kom ooreen met EvTom 26-33 en 77b, en P Oxy 655 met EvTom 24 en 36-397. Die Griekse P Oxy beslaan dus 21 van die 114 Jesus-logia wat in die Kopties EvTom voorkom $^{8}$.

Alhoewel die Nag Hammadi-tekste reeds in 1945 ontdek is, het dit 'n geruime tyd geneem voordat die eerste publikasie uit hierdie biblioteek van tekste die lig gesien het ${ }^{9}$. Eers in 1957 het Labib, die direkteur van die Koptiese Museum in Kairo, besluit om 'n baie klein gedeelte van die Nag Hammadi biblioteek aan die leserspubliek bekend te stel deur ' $\mathrm{n}$ aantal bladsye van die biblioteek in fotografiese vorm te publiseer, wat onder andere die EvTom ingesluit het (Fallon \& Cameron 1988:4196; Kloppenborg et al 1990:82). Feitlik onmiddellik hierna het Garrite, deur gebruik te maak van Labib se publikasie, 'n Franse vertaling van die proloog van die EvTom, asook EvTom 1-7, 26-33, 39-39 en 77 ( $d$ w s die Jesus-logia in die Koptiese EvTom wat ooreenkom met die Griekse fragmente in P Oxy 1, 654 en 655) die lig laat sien. Hierdie publikasie is gevolg deur dié van Garrite en Cerfaux wat bestaan het uit 'n Franse vertaling en bespreking van al die koninkrykgelykenisse in die EvTom (Fallon \& Cameron 1988: 4197).

Dit was egter eers in 1958, dus dertien jaar nadat die EvTom ontdek is, dat Leipoldt die eerste volledige vertaling van die EvTom gepubliseer het deur ook gebruik te maak van Labib se fotografiese afdruk. Later het Leipoldt wel toegang verkry tot die kodekse in Kairo, maar ongelukkig kon sy transkripsie en 'n hersiene vertaling (nou gebaseer op die fragmente self), tesame met ' $n$ inleiding tot en bespreking van elke logion, eers in 1967 na sy dood gepubliseer word (Fallon \& Cameron 1988:4197). In 1959 verskyn die sogenaamde editio princeps en vertaling van die Koptiese EvTom in Nederlands, Duits, Frans en Engels deur Guillaumont, Puech, Quispel, Till en 'Abd al Masih. In hierdie werk van Guillaumont et al (1959) word die teks van die Koptiese EvTom die eerste keer werklik vasgestel en ingedeel in 114 logia (Fallon \& Cameron 1988:4197; Riley 1994:228). Vir lank was hierdie werk dan ook die standaardwerk wat veral die teks en vertaling van die Koptiese EvTom betref. In 1989 verskyn, onder redaksie van Layton, Brill se uitgawe van onder andere die Koptiese EvTom, getiteld Nag Hammadi Codex II, 2-7, bestaande uit Lambdin se vertaling, Layton se weergawe van die Koptiese teks, Attridge se kollasie van Griekse fragmente wat in die EvTom voorkom, 'n inleiding deur Koester ten opsigte van die EvTom, asook 'n index verborum en katalogus van al die grammatiese vorme in EvTom deur Emmel. Tot op hede is hierdie werk van Layton $e t$ al die standaardwerk wat betref die bestudering van die Koptiese en Griekse teks en vertaling van die EvTom ${ }^{10}$. 


\section{DIE TOMASEVANGELIE: AFHANKLIK OF ONAFHANKLIK VAN DIE SINOPTIESE EVANGELIES?}

Die mees kontroversiële aspek rakende die EvTom is die vraag of die EvTom getuienis is van 'n onafhanklike tradisie wat teruggevoer kan word na Jesus, of dat die EvTom gesien moet word as die bron van die tradisies wat ons in die Sinoptici vind. Riley formuleer hierdie belangrike aspek van Tomasnavorsing soos volg:

The single most controversial issue facing scholars is whether or not the GTh is a genuine witness to an independent stream of tradition reaching back to Jesus: did the author(s) of the GTh copy and interpret sayings from the written texts of the canonical Gospels, or compose the text based in an independent tradition?

(Riley 1994:232; kyk ook Kloppenborg et al 1990:85; my beklemtoning)

Navorsers wat hulle met Tomasnavorsing besig hou, kan in hierdie verband in drie groepe verdeel word: eerstens is daar diegene wat van mening is dat die EvTom nie 'n onafhanklike tradisie verteenwoordig nie (bv Briscoe, Sheppard, Lindemann, Cerfaux, Schnider, Dehandschutter, Gärtner, Grant, Freedman, Haenchen, Kasser, Leipoldt, McArthur, Munck, Schippers, Schoedel, Schrage, Blomberg, Fledderman en Schürmann). Ander geleerdes weer meen dat die EvTom nie afhanklik is van die Sinoptiese tradisie nie, en sluit navorsers in soos Montefiore, Jones, Menestrina, Petersen, Horman, McCaughy, Hunzinger, Crossan, Cullmann, Davies, Koester, MacRae, Quispel en Sieber. Dan is daar diegene wat van mening is dat die EvTom gebruik gemaak het van beide onafhanklike tradisies en dié wat ons in die Sinoptici vind (bv Ménard, Doresse, Puech, Wilson, Chilton, Snodgrass, Baarda, Neller en Hedrick).

\subsection{Die Tomasevangelie: Afhanklik van die Sinoptiese evangelies}

In sy monograaf saam met Freedman neem Grant die standpunt in dat die EvTom van die Sinoptici gebruik gemaak het. Hy is van mening dat die byvoegings, weglatings, transposisies en konflasies in die EvTom ten opsigte van die Sinoptici tipies is van byvoorbeeld die Naäseners se gebruik van die kanonieke evangelies in die tweede eeu. Ook wanneer daar byvoorbeeld vormkrities aangetoon word dat 'n bepaalde gelykenis in die EvTom meer oorspronklik is as die sinoptiese parallelle, handhaaf Grant. sy standpunt van afhanklikheid. Die rede hiervoor is sy siening dat, waar die vormkritiek beslis die beste teorie is om mondelinge tradisies te ondersoek, dit nie die geval is as dit kom by skriftelike tradisies soos die EvTom en die Sinoptici nie (Fallon \& Cameron 
1988:4213) ${ }^{11}$. Grant is later in sy teorie deur Munck ondersteun. Munck toon egter aan dat die vrye gebruik van die kanonieke evangelies nie, soos Grant beweer, tot die Naäseners beperk was nie, aangesien byvoorbeeld die apostoliese vaders en Justinus ook die kanonieke evangelies met redelike vryheid aangewend en interpreteer het (kyk Fallon \& Cameron 1988:4213).

McArthur (Fallon \& Cameron 1988:4212) argumenteer ook dat die EvTom afhanklik van die Sinoptici is. Hy baseer sy standpunt op die volgende drie argumente: Matteus en Lukas het Markus as bron gebruik, en daarom is Matteus en Lukas se weergawes van Markus interpretasies/aanwendings van Markus. Dit dui nie op onafhanklike tradisies nie. Derdens, wanneer daar in die EvTom Matteaanse of Lukaanse weergawes van Markus voorkom, beteken dit noodwendig dat die EvTom van Matteus en Lukas gebruik gemaak het, en nie van 'n ander onafhanklike tradisie nie.

Tomasnavorsers het, in reaksie op McArthur se teorie, onder andere drie besware teen sy teorie geopper:

* McArthur verstaan die ontwikkeling van mondelinge tradisie te monolities, dit wil sê, te sterk liniêr. In die eerste eeu was Jesus-tradisies nie die alleenbesit van byvoorbeeld die Evangelies nie, ook ander groepe het Jesus-tradisies oorvertel (vgl o a Robinson \& Koester 1971; Pagels 1990). Matteaanse en Lukaanse variasies van Markusmateriaal kan dus ook beteken dat hulle uit 'n ander onafhanklike tradisie, in kompetisie met Markus, kom. McArthur het op hierdie beswaar gereageer deur te argumenteer dat, indien 'n blok van sodanige materiaal in die EvTom voorkom, hy sal aanvaar dat die EvTom van 'n ander onafhanklike tradisie - in kompetisie met Markus - gebruik gemaak het. Syns insiens is sodanige materiaal in die EvTom egter nie aantoonbaar nie (Fallon \& Cameron 1988:4212).

* Wilson is van mening dat daar ' $n$ vroeë Griekse stadia van die EvTom was, parallel met, maar onafhanklik van, die kanonieke evangelies. Met die vertaling van die Griekse EvTom na Kopties, kon dit gebeur het dat die vertaler bewustelik aanpassings in sy vertaling gemaak sodat die Koptiese EvTom ooreenkom met die Koptiese weergawe van die Nuwe Testament. Indien dit waar sou wees, is die EvTom nie afhanklik van die Sinoptici nie, al lyk dit so as gevolg van die Koptiese vertaling daarvan. McArthur antwoord hierop deur te argumenteer dat nie alleen die Koptiese weergawe van die EvTom afhanklikheid toon wat betref die kanonieke evangelies nie, maar ook die Griekse manuskripte (P Oxy 1, 654 en 655) van die EvTom wat ons tot ons beskikking het (kyk Fallon \& Cameron 1988:4215).

* 'n Verdere beswaar van Wilson ten opsigte van McArthur se teorie is dat dit ook moontlik kan wees dat die EvTom van tradisies binne sowel as buite die kanonieke 
evangelies gebruik gemaak het. McArthur se reakse hierop is dat, indien daar erken word dat sekere tradisies in die EvTom wel van die Sinoptici afhanklik is, die bewyslas op diesulkes is om aan te toon dat sommige tradisies nie van die Sinoptici stam nie.

Haenchen (kyk Fallon \& Cameron 1988:4215) skaar hom ook by diegene wat van mening is dat die EvTom van die Sinoptici afhanklik is, maar postuleer 'n baie meer verfynde tesis in hierdie verband as byvoorbeeld Grant en McArthur. Volgens Haenchen het die skrywer van die EvTom nie met verskeie kopieë van die Nuwe Testament voor hom gesit en, in die skryf daarvan, dan ' $n$ tradisie uit een evangelie en dan weer uit ' $n$ ander evangelie gekies nie. Syns insiens het die skrywer van die EvTom eerder staatgemaak op mondelinge tradisies in gnostiese sirkels wat bestaan uit die gnostiese gebruik en interpretasie van die Sinoptiese tradisie in die eerste twee eeue. Hy pleit dus vir ' $n$ indirekte afhanklikheid van die sinoptiese tradisie. Dehandschutter (1992:2257-2262) ondersteun Haenchen in hierdie verband. In aansluiting by Fieger (kyk Dehandschutter 1992:2258) meen hy dat die EvTom 'n goeie voorbeeld is van die gnostiese ontvangs en gebruik van die sinoptiese tradisie. Die Christelik-gnostiese inspirasie van die redaktor verskaf so die rede vir die feit dat die EvTom 'n versameling van Jesus-logia is, en verklaar ook die ontbrekende narratiewe struktuur daarvan.

Schrage, op sy beurt weer, meen dat ' $n$ tekskritiese vergelyking van die Koptiese EvTom met die Koptiese vertaling van die Nuwe Testament daarop dui dat die EvTom van die Koptiese vertaling van die Nuwe Testament afhanklik is. Op grond van die ooreenkomste tussen hierdie twee vertalings oordeel hy dat dit logies is om te konkludeer dat, aangesien die Koptiese vertaling van die Nuwe Testament van die Sinoptiese tradisie afkomstig is, dieselfde vir die Koptiese EvTom geld. Dit is natuurlik 'n vraag of die Koptiese vertaling van die Nuwe Testament kronologies vroeër as die Koptiese EvTom is (soos Schrage beweer), en of die Koptiese EvTom nie eerder die Koptiese vertaling van die Nuwe Testament beïnvloed het, presies dit wat Schrage nie argumenteer nie (kyk Kloppenborg et al 1990:86; Fallon \& Cameron 1988:4216).

Verskeie Tomasnavorsers, wat konsentreer op die bestudering van die gelykenisse in die EvTom ${ }^{12}$, kom ook tot die konklusie dat die EvTom van die sinoptiese tradisie afhanklik is. Die uitstaande kenmerk van die gelykenisse in die EvTom is dat hulle, anders as die geval in die sinoptiese evangelies, geen allegoriserings bevat nie. Waar Dodd (1961) en Jeremias (1972) aangetoon het dat die allegorisering van die gelykenisse van Jesus in die evangelies heel waarskynlik op 'n sekondêre ontwikkeling in die vroeë kerk dui, daar beweer Briscoe en Sheppard, Schoedel, Fledderman en Lindemann juis die omgekeerde: die afwesigheid van allegoriese tendense in die gelykenisse in die EvTom dui daarop dat alle allegorisering in die EvTom bewustelik deur ' $n$ gnostiese skrywer weggelaat is om of by die EvTom se gnostiese agtergrond, of 
by sy gnostiese teologie, of dalk by albei aan te pas (Fallon \& Cameron 1988:4210). So beweer Fledderman, in 'n studie van EvTom 20 (die gelykenis van die mostertsaad) en EvTom 96 (die gelykenis van die suurdeeg) dat, in hierdie twee gevalle ten minste, die EvTom 'n Markaanse en Matteaanse redaksie van $Q$ bevat (Riley 1994:235). So ook is Tuckett, na aanleiding van sy analise van EvTom 9 (die gelykenis van die saaier), van mening dat die EvTom afhanklik is van die kanonieke evangelies, aangesien EvTom 9 duidelik 'n gnostiese edisie van Markus is (kyk Riley 1994:235).

\subsection{Die Tomasevangelie: Onafhanklik van die Sinoptiese evangelies}

Onder diegene wat van mening is dat die EvTom onafhanklik is van die sinoptiese tradisie tel geleerdes soos Montefiore, Summers, Saurez, Jones en Menestrina, Petersen, Horman, McCaughy, Hunzinger, Crossan, Cullmann, Davies, Koester, MacRae, Quispel en Sieber. Hierdie wetenskaplikes verskil egter oor die bronne van die EvTom: sommiges meen dat die EvTom sy stof in nie-kanoniese evangelies gevind het, terwyl ander weer van mening is dat die skrywer van die EvTom sy bronne gevind het in een (of meer) verlore versamelings van Jesus-logia.

\subsubsection{Nie-kanoniese evangelies as bron van die Tomasevangelie}

Die mees bekende hipotese in hierdie verband is dié van Quispel. Uitgaande van die feit dat Klemens van Aleksandrië variante van EvTom 2 aan die Evangelie van die Hebreërs toegeskryf het, en variante van EvTom 22 aan die Evangelie van die Egiptenare, oordeel Quispel dat die EvTom 'n versameling van Jesus-logia is wat uit hierdie twee evangelies geneem is. In die verdere begronding van sy teorie wys hy op die verskeie doeblette in die EvTom (bv o a EvTom 48 en 106; EvTom 55 en 101; EvTom 38 en 92; EvTom 39 en 102). 'n Verdere interessantheid is, volgens hom, dat waar doeblette voorkom, die een logion van die doeblet 'n Joods-Christelike teologiese tendens verteenwoordig en die ander logion 'n enkratitiese teologie ${ }^{13}$. Die JoodsChristelike bron sou dan die Evangelie van die Hebreërs wees, en die enkratitiese bron die Evangelie van die Egiptenare. Quispel het later ook 'n derde bron van die EvTom geïdentifiseer, te wete 'n Hermetiese gnomologium, bestaande uit Hellenistiese spreuke wat handel oor kennis van die self (Fallon \& Cameron 1988:4217-4218). Laastens is hy van mening dat sekere logia in die EvTom skeppings van die skrywer self is. Omdat in die jare 1960 tot 1970 min werklike kennis van die Evangelie van die Hebreërs en die Evangelie van die Egiptenare was, het Quispel se teorie nie baie veld gewen nie. Dit word egter wel ondersteun deur Till en Van Unnik (kyk Fallon \& Cameron 1988:4218) 


\subsubsection{Een of meer verlore versameling(s) van Jesus-logia as bron van die Tomasevangelie}

Op grond van die sentrale rol wat aan die persoon van Jakobus in sowel EvTom 12 as in die Joodse Christendom toegeken word, is Cullmann van mening dat die skrywer van die EvTom van 'n Joods-Christelike tradisie/bron gebruik gemaak het. Volgens sy oordeel behoort die verband tussen die EvTom en die pseudo-Klementynse literatuur daarom verder ondersoek te word aangesien laasgenoemde in Joods-Christelike kringe ontstaan het (Fallon \& Cameron 1988:4219). Friend en Grobel is ook van mening dat die wortels van die EvTom in een of ander Joods-Christelike bron gesoek moet word (so ook Strobel en Bartsch).

Montefiore weer, in sy bestudering van die gelykenisse in die EvTom, kom tot "n verskillende gevolgtrekking ten opsigte van die bron(ne) van die EvTom as Briscoe en Sheppard, Schoedel, Fledderman, Tuckett en Lindemann (kyk weer Afd 2.1). Deur veral gebruik te maak van Jeremias se kategorieë in sy studie van die gelykenisse (bv dié van embellishment, the change of audience, allegorization, conflation en setting; kyk Jeremias 1972:113-114) kom Montefiore tot die konklusie dat die EvTom nie afhanklik van die Sinoptici kan wees nie. Montefiore word in hierdie verband deur Jones en Menestrina ondersteun (kyk Fallon \& Cameron 1988:4210).

Koester, hoofsaaklik in reaksie op die werk van Schrage (kyk Afd 2.1), toon myns insiens oortuigend aan dat die EvTom nie van die sinoptiese tradisie afhanklik is nie. Volgens Koester is daar net een wyse waarop die afhanklikheid of onafhanklikheid van die EvTom ten opsigte van die sinoptiese evangelies bepaal kan word: 'the rigorous employment of form-critical criteria as a necessary means of determining literary dependence' (Robinson \& Koester 1971:114). Wanneer daar konsistent met vormkritiek gewerk word meen Koester dat dit gou duidelik word dat veral die gelykenisse in die EvTom nie 'the obvious allegorical shaping and elaborate interpretations that have come to be associated with the redaction and theology of the synoptic evangelists' het nie (Robinson \& Koester 1971:129). Volgens Koester kan daar op grond van laasgenoemde net een afleiding gemaak word: die Jesus-logia in die EvTom moet vroeër gedateer word as die tradisies in die Sinoptici, en daarom kan die EvTom nie afhanklik van die kanonieke evangelies wees nie.

Sieber kompleménteer Koester se werk deur naas die klem op die vormkritiek, ook die klem op redaksiekritiek te plaas. Volgens Sieber kan die EvTom alleen van die sinoptiese tradisie afhanklik wees indien redaksie-histories aangetoon word dat die skrywer van die EvTom die redaksionele arbeid van die skrywer van Lukas oorgeneem het. Met ander woorde, indien aangetoon kan word dat die EvTom die 'teologie' van Lukas in sekere logia of gelykenisse oorgeneem het, dan kan daar wel aangeneem word dat 
die EvTom afhanklik van die sinoptiese tradisie is. Syns insiens kon Schrage egter nie aantoon dat die EvTom byvoorbeeld die 'teologie' van Matteus in bepaalde logia en/of gelykenisse oorgeneem het nie (Fallon \& Cameron 1988:4219-4222; Riley 1994: 233).

In aansluiting by Koester en Sieber argumenteer Stroker dat vier eienskappe van die EvTom daarop dui dat dit onafhanklik van die sinoptiese evangelies is: die totaal ander volgorde van Jesus-logia in die EvTom teenoor die volgorde van dieselfde Jesuslogia in die Sinoptici, die teenwoordigheid van materiaal in die EvTom wat, op grond van vormkritiese oorwegings, blyk 'n vroeër stadia van die tradisie te bewaar as dié in die Sinoptici, asook die afwesigheid van spesifieke elemente in die tradisie wat aan die aktiwiteit van die evangeliste toegeskryf kan word. Laastens is Stroker van mening dat, aangesien die EvTom sekere gelykenisse bevat wat nie in die Evangelies voorkom nie, die EvTom tradisies bevat wat vroeër as dié in die Sinoptiese evangelies. Die EvTom kan dus nie van die kanonieke tradisie afhanklik wees nie (kyk Fallon \& Cameron 1988:4219-4223; Riley 1994:233-234).

Kloppenborg et al (1990:86-88) is ook van oordeel dat die EvTom nie afhanklik van die Sinoptiese evangelies is nie. Hulle baseer hulle standpunt op die volgende drie kragtige argumente:

* Daar moet aanvaar word dat in die EvTom, soos in alle ander antieke manuskripte, oorskryffoute, emendasies en harmonisering sal voorkom. Met hierdie 'ancient scribal practice' as gegewenheid, asook op grond van die feit dat daar minstens 70 parallelle tussen die EvTom en die Sinoptici is, is die paar gevalle waar afhanklikheid van die EvTom ten opsite van die Sinoptiese tradisie aangetoon kan word, nie werklik gronde vir die bewys van afhanklikheid nie. Wat dit wel aandui is dat die EvTom beslis, soos alle ander antieke geskrifte, sekondêre ontwikkeling ondergaan het, alhoewel onafhanklik van die Sinoptiese tradisie.

* Die parallelle tekste tussen die EvTom en die Sinoptiese evangelies beslaan ongeveer net die helfte van die logia in die EvTom. Dit beteken dat die skrywer van die EvTom beslis ook toegang tot nie-kanonieke bronne moes gehad het.

* Dit is belangrik om raak te sien dat die EvTom uit 'n versameling van Jesus-logia bestaan wat nie aanmekaar gebind word deur een of ander narratiewe struktuur nie. Robinson \& Koester (1971) het oortuigend aangetoon dat die narratiewe evangelie (soos die Sinoptici) se tendens was om die 'sayings tradition' te absorbeer en te vervang ( $\mathrm{vgl}$ bv $\mathrm{Q}$ en Mark 4). Om hierdie rede is die EvTom een van die weinige versamelings van Jesus-logia in die primitiewe Christelike literêre genre wat nie deur die narratiewe evangelies geabsorbeer is nie. 
Op grond van bogenoemde drie argumente kan Kloppenborg et al (1990) nie anders as om te konkludeer dat die EvTom 'n onafhanklike, outonome tradisie verteenwoordig nie, ' $n$ tradisie diep ingebed in dieselfde vroeg-Christelike tradisies wat deur die Sinoptici gebruik is.

Laastens moet die werk van Patterson (1993) hier genoem word. Patterson argumenteer oortuigend dat, op grond van vorm en inhoud, die EvTom nie afhanklik van die Sinoptiese tradisie kan wees nie. Patterson baseer sy standpunt ten opsigte van die EvTom se onafhanklikheid verder op sy verstaan van die sosiale agtergrond en geskiedenis van die EvTom. Deur gebruik te maak van die vroeëre werk van Gerd Theissen beskou hy die Tomasgemeenskap as bestaande uit rondgaande charismate/radikale. Op grond van EvTom 12 (waar na Jakobus se outoriteit verwys word), meen Patterson dat die 'basiese Tomasversameling' reeds voor 62 n C (die martelaarsdood van Jakobus) bestaan het. EvTom 13 (waar die outoriteit na Tomas oorgedra word) en EvTom 114 is volgens Patterson latere byvoegings tot die EvTom ${ }^{14}$.

\subsection{Die Tomasevangelie: Onafhanklik en afhanklik van die Sinoptiese evangelies}

Onder die navorsers wat van oordeel is dat die EvTom tradisies bevat wat sowel afhanklik en onafhanklik van die kanonieke Evangelies is, kan die name van Ménard, Doresse, Puech, Wilson, Snodgrass, Baarda, Chilton, Neller en Hedrick genoem word.

Volgens Ménard is die EvTom 'n gnostiese dokument van Siriese oorsprong wat hoofsaaklik, maar nie uitsluitlik, van die Sinoptiese tradisie afhanklik is (Fallon \& Cameron 1988:4199). So ook Doresse: die EvTom bevat gedeeltelik die Sinoptiese tradisie, maar bevat ook outentieke Jesus-logia uit 'n verlore versameling van Jesus-logia. Volgens hom het die skrywer(s) van die EvTom die teks van die EvTom gevorm deur lae van kanoniese en nie-kanoniese Jesus-logia agtereenvolgens opmekaar te stapel. Hierdie oortuiging baseer hy op die feit dat daar in geskrifte van die kerk uit die derde en vierde eeu baie dikwels na die EvTom verwys word, wat daarop dui dat die EvTom in die eerste eeue wyd gelees, en daarom ook voortdurend uitgebrei is.

Dat die EvTom uit 'n mengsel van afhanklike en onafhanklike tradisies ten opsigte van die Sinoptici bestaan, baseer Puech op die verskil tussen P Oxy 6545 en EvTom 5. In die Griekse weergawe van EvTom 5 (= P Oxy 654 5) word 'n moontlike verwysing na die opstanding van Jesus gevind (deur die byvoeging van die Griekse werkwoord $\dot{\varepsilon} \gamma \varepsilon \rho \theta \dot{\eta} \sigma \varepsilon \tau \alpha \iota$ ), 'n verwysing wat nie in die Koptiese EvTom (d w s, EvTom 5) voorkom nie. Op grond van hierdie verskil onderskei Puech tussen twee resensies van die EvTom: een wat aanvaarbaar was vir die opkomende ortodokse kerk, en een wat gegeld het in meer heterodokse kringe (kyk Fallon \& Cameron 1988:4221).

Wilson, op sy beurt weer, oordeel dat die kern van die EvTom van 'n tradisie onafkanklik van die Sinoptiese tradisie kom, maar dat in latere verwerkings hierdie 
onafhanklike bron sinoptiese beïnvloeding ondergaan het. Laasgenoemde is min of meer ook die standpunt van Chilton. Volgens Chilton moet die EvTom in die tweede eeu n $\mathrm{C}$ gedateer word, maar bevat die EvTom ook vroeë onafhanklike materiaal soos EvTom 54, 82 en 99, asook gedeeltelik onafhanklike Jesus-logia soos EvTom 3, 46b en 113 (Riley 1994:235-236). So ook Snodgrass en Baarda: die EvTom is vir sy grootste gedeelte afhanklik van die Sinoptiese tradisie, maar bevat ook bepaalde logia wat onafhanklik van die Sinoptiese tradisie is.

\section{DATERING ${ }^{15}$}

In die moontlike datering van die EvTom kan daar met redelike sekerheid met 'n terminus ad quem van 300-350 n C gewerk word aangesien meeste navorsers die Koptiese EvTom rondom hierdie datum dateer. Voorbeelde van navorsers wat 'n datering van ongeveer 300-350 n C ondersteun, is Doresse, Quispel, Grenfell \& Hunt, Baarda, Fieger, Schrage, Koester, Kloppenborg et al, Funk et al en Pagels, terwyl Till (400 n C) en Leipoldt ( $500 \mathrm{n} \mathrm{C)}$ dit effens later dateer. Layton meen egter ook dat, op grond van die handskrif van die Nag Hammadi-biblioteek, die Koptiese EvTom gedateer behoort te word tussen 300-350 n C (kyk Fallon \& Cameron 1988:4224).

Daar moet egter ook in ag geneem word dat ' $n$ datum tussen $300-350 \mathrm{n} C$ slegs dui op die periode waartydens die Koptiese teks van die EvTom of oorgeskryf is vanaf 'n ander kopie, of vertaal is vanuit die Grieks (Riley 1994:228). Hierbo is reeds beskryf hoe Grenfell \& Hunt (kyk weer Afd 1) in 1897 en 1904 raakgesien het dat die fragmente genoem P Oxy 1, 654 en 655 Griekse variante van bepaalde logia in die Koptiese EvTom is. Volgens hulle interpretasie, op sowel ortografiese as paleografiese gronde, was hulle van mening dat $\mathrm{P}$ Oxy 1 nie later as $200 \mathrm{n} \mathrm{C}$ geskryf was nie, en dat $P$ Oxy 654 en P Oxy 655 teen ongeveer 300 n C gedateer behoort te word. In 'n latere werk het hulle egter ook die mening uitgespreek dat $P$ Oxy 'beslis vroeër as $140 \mathrm{n} \mathrm{C}$ is' (Fallon \& Cameron 1988:4224). Grenfell \& Hunt plaas P Oxy 1 dus ongeveer in die middel van die tweede eeu ( $\mathrm{d}$ w s so min of meer $150 \mathrm{n} \mathrm{C}$ ), 'n datering wat vandag nog deur die meeste Tomasnavorsers aanvaar word (vgl bv Patterson, Kloppenborg et al, Fallon \& Cameron, Funk et al, Riley).

Verskeie navorsers meen dan ook dat, juis op grond van bogenoemde datering van $P$ Oxy 1, die EvTom gedateer moet word teen ongeveer die middel tot einde tweede eeu (d w s 150-200 n C). Voorbeelde van navorsers wat vir hierdie datering kies, is onder andere Baarda (wat die EvTom as 'n gnostiese florilegium uit die tweede eeu sien), Fieger, Schrage, Dehandschutter, Snodgrass, Quispel, Drijvers, Schoedel, Grant \& Freeman, Munck, McArthur en Strobel (kyk Fallon \& Cameron 1988:4214-4120).

Indien die standpunt egter ingeneem word dat die EvTom nie van die sinoptiese evangelies afhanklik is nie en daarom 'n onafhanklike tradisie verteenwoordig, kan die 
EvTom nog vroeër gedateer word. Indien aanvaar sou word dat Markus in ongeveer 72 n C geskryf is, Matteus teen ongeveer 85 n C en Lukas teen ongeveer 96 n C, beteken dit dus dat die EvTom se terminus ad quem terugskuif tot uiters die einde eerste eeu. Dit sou beteken dat die EvTom iewers in die tweede helfte van die eerste eeu geskryf is. Om egter ' $n$ meer spesifieke datum van skrywe aan die EvTom in hierdie tydperk toe te ken is nie so maklik nie.

Wat die keuse vir 'n meer spesifieke datum tussen 50 en 100 n C so moeilik maak is dit wat die onstabiliteit van die evangelietradisie in hierdie tydperk genoem kan word (kyk Kloppenborg et al 1990:88-89). Ons weet byvoorbeeld dat die tekste van die kanonieke evangelies verskeie redaksies ondergaan het vanaf skrywe totdat die teks vasgestel is. Goeie voorbeelde hier is Johannes 20 en 21, asook die wyse waarop Matteus en Lukas van Markus gebruik gemaak het. Nuwe-Testamentici (wat van die tweebronne-hipotese as vertrekpunt neem) aanvaar dat Matteus en Lukas van Markus gebruik gemaak het in die skryf van hulle onderskeie evangelies. Lukas laat egter 'n taamlike lang gedeelte uit Markus weg (Mark 6:45-8:26), 'n gedeelte wat Matteus wel oorneem. Op grond hiervan konkludeer verskeie Nuwe-Testamentici dat Matteus 'n 'langer' en Lukas 'n 'korter' Markus as teks gebruik het ${ }^{16}$. Antieke tekste, soos die kanonieke evangelies, was dus redelik 'onstabiel' in hulle vroeë jare van oorlewering. Wanneer daar in ag geneem word dat die EvTom 'n 'sayings collection/sayings gospel' sonder ' $n$ narratiewe struktuur is, was bogenoemde probleem van onstabiliteit ten opsigte van die EvTom dus selfs miskien van groter omvang as wat betref die kanonieke evangelies. Wat dit dus moeilik maak om die EvTom te dateer is dat dit heel waarskynlik tradisies bevat wat baie vroeg is (so vroeg as Jesus self), maar ook ander tradisies wat veel later tot die versameling gevoeg is.

Tog meen Koester, sowel as Patterson (1993:113-118) en Funk et al (1993:474), dat die EvTom ons inhoudelik toelaat om die dokument meer spesifiek te dateer. In die eerste plek meen Koester dat, veral op grond van die proloog van die EvTom (= EvTom P), EvTom 12 en EvTom 13, die dokument sy ontstaan in 'n tydperk in die vroeë kerk gehad het toe dit gebruik was om die gesagsposisie van 'n bepaalde aspostel in ' $n$ bepaalde gemeenskap in te span om gesag aan ' $n$ bepaalde dokument te verleen. Koester stel dit soos volg:

Attribution of authorship to Didymos Judas Thomas ... situates the text at a time in which appeals to authority were made to individual disciples or apostles by name, in order to secure the identity and guarantee the reliability of the tradition of those communities which looked to such individuals as their founder.

(Koester, in Fallon \& Cameron 1988:4226) 
Die feit dat EvTom P na Tomas verwys, dat in EvTom 12 na Jakobus se gesag verwys word, en dat hierdie gesag van Jakobus (en ook die van Petrus en Matteus) in EvTom 13 met dié van Tomas vervang word, illustreer dus vir Koester dat die EvTom uit 'n tydperk kom waarin die beroep op die outoriteit van apostoliese figure aan die orde van die dag was, 'n tydperk waarin byvoorbeeld die deutero-Pauliniese geskrifte onstaan het.

'n Verdere belangrike aspek in die EvTom wat 'n meer spesifieke datering moontlik maak is dit feit dat die EvTom 'die Twaalf' nie as 'n afgebakende, kwasi-heilige groep hanteer nie. In EvTom 13, byvoorbeeld, word Tomas se antwoord voorgehou as die korrekte, maar dié van Petrus en Matteus as onvoldoende. Volgens Koester dui dit daarop dat die EvTom geskryf is in 'n tydperk voor die dissipels as 'n groep, as die sogenaamde 'Twaalf' begin 'verafgod' is, dus ongeveer in die tyd van die skrywe van Markus, en voor die skrywe van Handelinge. Dit laat ons met 'n tydperk van ongeveer 70-100 n C (kyk Fallon \& Cameron 1988:4227; Kloppenborg et al 1990:89-90). Koester (1990:49-172) se finale keuse is egter vroeër as die kanonieke Evangelies, ongeveer $60 \mathrm{n} \mathrm{C}$.

Patterson (1993:113-118), Funk et al (1993:474) en Davies (kyk Fallon \& Cameron 1988:4225-4226) kies ook vir 'n vroeë datum. Volgens Davies moet die EvTom gedateer moet word tussen 50-70 n C, dit wil sê, in dieselfde tyd as Q. Davies baseer sy standpunt op die duidelike onafhanklikheid van die EvTom ten opsigte van die Nuwe Testament, die voorkoms van Joodse wyheidspekulering in die teks, asook die afwesigheid van Gnostiese idees en mitologie in die EvTom.

Patterson, op sy beurt weer, kies vir 'n datum van 62 n C, 'n datum wat deur Crossan aanvaar word. Patterson grond sy keuse hoofsaaklik in die argumente van Koester, maar is verder van mening dat die EvTom vergelyk behoort te word met dokumente soos $\mathrm{Q}$, of dan met Markus 4. Beide hierdie twee dokumente/tradisies (as 'sayings collections') is later in die meer biografiese en narratiewe genres van die vroeë Christendom opgeneem. Alhoewel dit nie die lot van die EvTom was nie, kom laasgenoemde uit dieselfde tydperk as $\mathrm{Q}$ en Markus 4 as mondelinge tradisie, dit wil sê, voor $65 \mathrm{n} \mathrm{C}$.

Laasgenoemde is ook die datering wat deur Funk et al (1993:474) gekies word. Volgens Funk bestaan die EvTom uit sowel baie vroeë as baie laat tradisies. Alhoewel die finale edisie van die EvTom so teen 100 n C sy beslag gekry het, meen Funk egter dat, op grond van ' $n$ vergelyking van die aard van sekere tradisies in die EvTom met dieselfde tradisies in die kanonieke evangelies, die vroegste teks van die EvTom teen ongeveer 50-60 n C gedateer behoort te word. 


\section{DIE TEOLOGIE VAN DIE TOMASEVANGELIE: GNOSTIES OF NIE?}

In die debat rondom die teologie van die EvTom is die besprekingspunt wat in die brandpunt staan, die vraag of die EvTom as 'n gnostiese dokument beskou moet word of nie. Verskeie Tomasnavorsers is van mening dat die EvTom wel as 'n gnostiese dokument beskou moet word, terwyl ander weer nie hierdie mening toegedaan is nie. Om op hierdie vraag te antwoord, maar ook om die standpunte in hierdie verband te beoordeel is dit, myns insiens, eers nodig om die gnostiek in sy mees ontwikkelde vorm te beskryf (kyk o a Funk et al 1993:500-501).

Die gnostiek as godsdienstige beweging het sy ontstaan in die eerste eeu en het verskeie ander godsdienstige bewegings, soos byvoorbeeld die Judaïsme(s) en die Christendom, geïnfiltreer. Die gnostiek se basiese uitgangspunt is die oortuiging dat die wêreld in sy wese boos/sleg is. Hierdie oortuiging word begrond in die leer oor die skepping van die wêreld: die wêreld het sy onstaan te danke aan die feit dat 'n demiurg of skeppergod (dikwels beskryf as 'n gevalle of opstandige engel) teen die een ware God gedraai het en die wêreld geskep het. Die wêreld (skepping) is daarom in wese die private domein van hierdie demiurg.

In die Joodse gnostiek word hierdie opstandige demiurg of skeppergod geïdentifiseer met Jahwe, die skeppergod van Genesis. Vanuit hierdie oortuiging verstaan Joodse gnostici die skeppingsverhaal as sou Jahwe die volle waarheid van die skepping nie aan Adam en Eva bekend gemaak het nie. Die slang word gesien as goed, die agent van die ware God wat Adam en Eva probeer oortuig van die ware hemelse realiteit, naamlik die ware God wat uitstyg bo en meer is as die bedorwe skepping van die demiurg Jahwe, dit waarvan hulle deel is. Die slang funksioneer dus as 'n soort reddersfiguur. Reddersfigure speel daarom ook 'n belangrike rol in die Gnostiese mitologie: deur hierdie figure, as die ware boodskappers van God wat deur God na die aarde toe gestuur word, word die mensheid oortuig van hulle bedorwe toestand en hulle ware bestemming. Wie die boodskap(pe) van hierdie reddersfigure verstaan en aan vaar, word dienooreenkomstig gered.

Die aanhangers van die gnostiek glo dat hulle nie van hierdie wêreld is nie, maar afstammelinge van die een ware God. Hulle beskou hulleself as vonkies van Goddelike lig wat deur die skepping van die demiurg vasgevang is in die verdorwe materiële wêreld van sy skepping. Hulle doel (redding) is om uit hierdie wêreld bevry te word en terug te keer na hulle hemelse oorsprong.

In die Christelike gnostiek word die reddersfiguur geïdentifiseer met Christus. Hy het gekom om, soos in ander gnostiese sisteme, die wat gehoor wil gee te herinner aan hulle ware natuur, hulle te laat ontwaak van hulle vergeetagtigheid wat betref hulle 
oorsprong en hulle te leer en oortuig van hulle ware hemelse tuiste. Om dit te bereik dra Christus aan hulle wat wil luister, bepaalde 'geheime kennis' (gnosis) oor wat die gnostici in staat stel om hulleself van hierdie bose en verdorwe aarde te bevry en na die ware Ood terug te keer (kyk Funk et al 1993:501).

Kom bogenoemde aspekte op so 'n wyse in die EvTom na vore dat dit as gnosties beskou kan word? Verskeie Tomasnavorsers soos Quispel, Frend, Grobel, Higgens, Ménard, Davies, Sieber, King, Cameron, Doran en Meyer is nie hierdie mening toegedaan nie. Volgens Quispel is die EvTom nie gnosties nie maar enkratities (asketies), 'n teologiese karakter wat die direkte produk is van die Joods-Christelike, enkratitiese en Hermetiese bronne wat die skrywer gebruik het in die skryf van sy evangelie. Quispel lys drie verdere redes waarom hy meen die EvTom nie gnosties kan wees nie:

* die EvTom bevat nie 'n ontwikkelde mitologie soos ander gnostiese geskrifte nie ${ }^{17}$;

* EvTom 28:1 (= P Oxy 1 28:1), waar Jesus sê dat Hy in die $\sigma \alpha \dot{\alpha} \rho \xi$ verskyn het, is duidelik anti-gnosties ${ }^{18}$; en

* daar is geen getuienis van die teenwoordigheid van gnostiese tendense in Edessa, die plek waar die EvTom (volgens Quispel) geskryf is nie ${ }^{19}$.

Quispel gee egter toe dat in die proses van die oorskryf van die teks dit wel moontlik is dat gnostiese interpolasies (soos bv EvTom 2, 4 en 8) hulle weg tot in die teks van die EvTom kon vind. Syns insiens is dit egter nog nie oortuigend bewys nie (Fallon \& Cameron 1988:4230-4231; Riley 1994:229).

In bogenoemde standpunt is Quispel veral ondersteun deur Kim, Davies, Frend, Grobel en Higgins, en onlangs veral deur De Conick en De Conick \& Fossum (Riley 1994:229) 20. Davies, byvoorbeeld, is van mening dat te veel Tomasnavorsers (soos bv Wilson en Turner) te maklik maar net aanvaar dat die EvTom gnosties is, sonder om dit werklik aan te toon. Volgens Davies bevat die EvTom nie, wat hy noem, enige 'meaningful or nuanced Gnosticism' nie (kyk Davies, in Fallon \& Cameron 1988:42304231 ), en moet eerder beskou word as 'n versameling van Jesus-logia wat gebruik was om nuut-gedoopte Christene te leer hoe om in die wêreld te gaan lewe. Die Sitz im Leben van die EvTom kan daarom beskryf word as die van 'postbaptismal instruction', aldus Davies (Fallon \& Cameron 1988:4230-4231) ${ }^{21}$.

Ook King, deur spesifiek aandag te gee aan die gelykenisse in die EvTom, oordeel dat die EvTom nie gnosties georiënteerd is nie: 'although it is clear that the Gospel of Thomas could - and did - lend itself easily to gnostic interpretation (especially 
through allegory), the text itself is not gnostic' (King, in Riley 1994:231). Cameron en Horan, in hulle studie van die gelykenisse in EvTom 96-98, kom ook (contra Lindemann, Cerfaux, Schoedel en Blomberg) tot dieselfde konklusie: die gelykenisse in die EvTom is 'independent products of oral tradition, not gnostic exegesis of written texts' (Cameron, in Riley 1994:231).

Ten slotte kan hier ook die standpunt van Meyer genoem word. Soos Cameron en Mack sien Meyer (1992:16) Jesus as 'an itinerant Cynic teacher' wat veral deur middel van aforismes en gelykenisse sy hoorders se verstaan van die wêreld bevraagteken het. Anders as wat die kerk bely, was Jesus nie 'n Goddelike apokaliptiese figuur nie, maar iemand wat 'n onkonvensionele wysheid ver-kondig het. Die EvTom bestaan hoofsaaklik uit hierdie aforismes en gelykenisse van Jesus, en kan daarom die beste as 'n 'gospel of wisdom' beskryf word (Meyer 1992: 10).

Verskeie Tomasnavorsers soos Grant, Haenchen, Kasser, Lindemann, Briscoe, Sheppard, Schoedel, Mees, Richardson, Klijn, Bauer, Gärtner, MacRae, Roques, Schrage, Turner, Wilson, Baarda, Summers, Vielhauer, Miller, Albanese, Puech en Fieger is op hulle beurt weer van die oortuiging dat die EvTom wel as 'n gnostiese dokument gesien moet word. Alhoewel hierdie Tomasnavorsers nie almal saamstem oor die meer spesifieke metodologie wat gevolg moet word in die ondersoek na die (gnostiese) teologie van die EvTom nie, is die meeste van hulle se uitgangspunt dieselfde: vergelyk die verskillende logia in die EvTom met hulle parallelle in die sinoptiese evangelies, en veranderings, byvoegings en ander tendense in die EvTom is 'n gnostiese redaksie van die sinoptiese tradisie.

Haenchen volg egter ' $n$ ander metodologie. Hy verkies om by die logia in die EvTom te begin wat volgens hom duidelik gnosties is. 'n Logion is gnosties wanneer die fundamentele perspektief van die gnostiek (nl dat partikels van hemelse lig, ingegiet in materiële partikels in mense teenwoordig is) in ' $n$ bepaalde logion voorkom. Wanneer die logia wat aan hierdie kriterum voldoen, bepaal is, word dit weer gebruik om die ander (nie-gnostiese) logia te ondersoek. Volgens Haenchen kan alleen hierdie metodologie reg laat geskied aan die wyse waarop EvTom P en EvTom 1 die verskillende logia in die EvTom beskryf: as gnostiese logoi apokryptoi, logia waarvan die betekenis nie op die oppervlakte lê nie (Fallon \& Cameron 1988:4232).

Ander navorsers wat die EvTom as gnosties beoordeel, poog op hulle beurt weer om die gnostiese element daarvan te verduidelik deur die EvTom aan 'n bepaalde gnostiese groep te koppel. So meen Cornélis, Grant, Schodel en Smyth dat die EvTom sy ontstaan aan die Naseense sekte uit die tweede eeu te danke het, terwyl Cerfaux en Gärtner weer die Valentiniëers sien as die gnostiese groep waaruit die EvTom stam 
(kyk Fallon \& Cameron 1988:4232) Haenchen is egter van mening dat die unieke mitologie van die Naseense sekte in die EvTom ontbreek, asook die unieke teologie van die Valentiniëers (Fallon \& Cameron 1988:4232).

'n Verdere benadering tot die ondersoek na die teologiese karakter van die EvTom is die bestudering van spesifieke begrippe in die EvTom. Hierdie metodologie word onder andere gevolg deur Miller, Albanese, Vielhauer, Leipoldt, Kee en Morard. Miller, byvoorbeeld, deur die begrip 'koninkryk' in die EvTom te ondersoek, kom tot die konklusie dat, in vergelyking met die kanonieke evangelies, hierdie begrip in die EvTom nie op ' $n$ bepaalde sfeer/plek dui nie, maar dat dit gerealiseer word deur die ervaring van kennis (Fallon \& Cameron 1988:4233). Albanese weer bestudeer die begrip 'inwardness', Vielhauer die begrip 'rus' en Leipoldt en Harl die begrip 'solitary one' (vgl EvTom 16). Interessant is die feit dat hulle navorsingsresultate, alhoewel nie dieselfde begrippe ondersoek word nie, taamlik met mekaar ooreenstem: die begrippe rus, 'inwardness' en 'solitary one' dui daarop dat die EvTom 'n praesentiese eskatologie voorstaan, te wete die terugkeer van die self na sy Goddelike oorsprong, 'n rus wat slegs deur kennis bereik kan word (Fallon \& Cameron 1988:4233).

'n Derde groep navorsers (o a Funk, Kloppenborg, Koester, Liebaert, SaveSorderberh, Layton en Lelyveld) beskou die EvTom as sou dit beide gnostiese en niegnostiese tendense bevat. Volgens Funk bevat die inhoud en boodskap van die EvTom inderdaad verskeie aspekte wat as die Christelike gnostiek beskryf kan word (kyk bo). Jesus, byvoorbeeld, word geteken as die ware verkondiger wat van God af kom. Jesus herinner sy volgelinge aan hulle vergeetagtigheid ten opsigte van hulle ware herkoms, leer dat hulle verligting nodig het om uit hulle bedorwe natuur te breek en verlostes van die ware God te word. Jesus staan verder in die EvTom negatief ten opsigte van die wêreld (vgl EvTom 21:6; 27:1; 56:1-2; 80:1-2, 110; 113:2), Hy herhinner mense aan hulle ware oorsprong (EvTom 49) en toon aan hoe iemand van hierdie wêreld bevry kan word (EvTom 50). Ook praat Jesus van sy terugkeer na die plek waarvandaan Hy gekom het (EvTom 38).

Aan die ander kant is daar egter 'n aantal logia van Jesus in die EvTom wat daarop dui dat die EvTom se oriëntasie nie volledig as gnosties beoordeel kan word nie. Die EvTom bevat geen leer oor die skepping, asook geen verwysing na die val van die skepping onder die demiurg nie. Daar is verder geen verwysing in die EvTom na die gevalle engel/demiurg nie, en verder wil dit lyk of die EvTom die Judaïsme in sy meer basiese en ortodokse vorm ken. Hierby kan ook gevoeg word dat verskeie logia in die EvTom geen gnostiese trekke het nie, veral daardie logia wat woordelikse parallelle in $Q$ en die kanonieke evangelies het, logia wat deur verskeie navorsers as die vroegste vorme van die tradisies wat ons in die kanonieke evangelies vind, beskou word. 
Op grond van hierdie eienskappe van die EvTom oordeel Funk et al (1993:501) dat die EvTom beskryf kan word as 'n dokument wat, gewortel in die Joodse wysheidstradisie (soos bv Psalm en Spreuke), as 'incipient' gnosties beskou kan word: die logia wat op die oog af gnosties blyk te wees, kan hoogstens beskryf word as logia met gnostiese tendense, logia wat, alhoewel hulle duidelik in 'n gnostiese rigting beweeg, nie as gnosties beskryf kan word nie. Die betrokke 'gnostiese' logia kan eerder beskou word as verteenwoordigend van 'n baie vroeë stadium van evangelievorming en teologisering in die vroeë kerk, vergelykbaar met sekere aspekte van die teologie van Paulus en dié van die kanonieke Johannesevangelie.

Koester ondersteun Funk in die sin dat ook hy van mening is dat, alhoewel verskeie logia in die EvTom gnostiese tendense bevat, die EvTom as sodanig nie as gnosties beskryf kan word nie. Die gelykenisse in die EvTom, as voorbeeld, beskou hy as onafhanklike produkte van die mondelinge tradisie, logia wat as stories in hulle eie reg gelees behoort te word, en nie as narratiewe wat kunsmatige uitdrukking aan een of ander geheime gnostiese idee(s) wil gee nie (Koester 1990:99). Syns insiens verkondig die EvTom eerder die teenwoordigheid van die Goddelike wysheid in die gelowige as die ware bestemming van die menslike bestaan. Hulle wat kan hoor en verstaan wat Jesus, as dié openbaring van die Goddelike wysheid leer, sal in staat wees om tot dieselfde wysheid te kom (Koester 1990:153). Die teologie van die EvTom beskryf hy daarom as 'n soort radikale enkratisme (cs asketisme, selfbeheersing en die afsondering van die liggaam) met 'n gnostiese oriëntasie as die norm van optrede vir die individuele dissipel in sy verhouding tot Christus. Die EvTom verteenwoordig so nie 'n hoogs ontwikkelde gnostiek nie, maar eerder 'that which was found in the environment of the Gospel of John' (Koester 1990:22; vgl Funk et al 1993:501). In hierdie opsig is die EvTom draer van twee dominante motiewe van die vroeg-Christelike verkondiging: die geradikaliseerde eskatologie van die koninkryk van God (d w s, die teenwoordigheid daarvan hier en nou), en die feit dat die realiteit van hierdie koninkryk in die woorde van Jesus, en die reaksie daarop, teenwoordig is (Koester 1990:153-155).

Twee ander standpunte in hierdie verband is dié van Layton en Liebaert. Layton is van die oortuiging dat die EvTom nie volledig gnosties of selfs Valentiniaans is nie. Die EvTom het eerder Valentinus geïnspireer om by 'n meer ontwikkelde 'hoëgnostiek' te kom. Die EvTom kan eerder verstaan word teen die agtergrond van die basiese Christendom as sou dit gebaseer wees op die Hellenistiese mite van die reis van die siel, sonder 'n radikale devaluasie van die kosmos en die oortuiging dat 'n demiurg die wêreld geskep het, oortuigings wat dikwels in 'n meer ontwikkelde gnostiek voorkom. Vanuit hierdie perspektief meen Layton dan dat die EvTom verstaan kan word deur middel van byvoorbeeld die Lied van die perrel in die nie-kanonieke Hande- 
linge van Tomas. In hierdie lied word beskryf hoe die siel die hemel verlaat, sy kleed in die hemel los en vasgevang word in die wêreld. 'n Boodskapper (Jesus, in die geval van die EvTom) wys die siel (die gelowiges) egter op sy ware bestemming, wat maak dat die siel terugkeer na die hemel waar hy dan weer sy kleed aantrek (vgl ook EvTom 84; Riley 1994:230).

Ook Liebaert, soos Layton, is van mening dat die EvTom wel 'n gnostiese agtergrond het en gnostiese tendense bevat, maar nie as gnosties gereken kan word nie. Syns insiens moet die gnostiese tendens(e) in die EvTom verstaan word in die sin dat die EvTom 'n alternatief bied op die Bybelse lering ten opsigte van moraliteit: alleen deur 'n gnostiese vergeesteliking van godsdienstige gebruike/eise kan daar toegang tot die hemel verkry word, nie deur die eties korrekte uitleef van die eise in die Bybel nie (Fallon \& Cameron 1988:4235). So gesien bied die EvTom ons 'n gnostiese interpretasie van wat die Bybelse moraliteit genoem kan word.

Ten slotte kan die standpunt van Kloppenborg et al (1990:94-99) hier genoem word. Volgens Kloppenborg moet die verskillende logia in die EvTom verstaan word as 'counter-cultural wisdom' (Kloppenborg et al 1990:94). Uitgaande van die standpunt 'that the world is not a hospitable place' funksioneer die gelykenisse in die EvTom onder andere om die gelowige op te roep om alle menslike/wêreldse waardes en prestasie te negeer en met entoesiasme te soek na 'one's true identity', 'n identiteit wat net gevind kan word in die korrekte verstaan van die woorde van Jesus. Wat is die korrekte verstaan van die woorde van Jesus? Eerstens die gewone dinge: om in te sien dat die gelowige nie selfsugtig mag wees nie (EvTom 41), dat daar nie oor ander geoordeel mag word nie (EvTom 26), en dat die gelowige daarteen moet waak om deur die wêreld verlei te word (EvTom 34). Tweedens is daar egter ook ander sake wat aangespreek word, en wat, wanneer dit met die gnostiek soos hierbo vergelyk word, duidelik in die rigting van die gnostiek neig: die gelowige moet poog om dit wat verborge is te vind (EvTom 5); dit wat verborge is, kan slegs gevind word indien die soeke daarna met inspanning gepaard gaan (EvTom 2); dat die gelowiges slegs die koninkryk sal vind indien hulle hulle ware identiteit vind as kinders van die lig (EvTom 49) en hulle ware rus in hierdie bose wêreld vind (EvTom 50).

Duidelik het laasgenoemde aantal logia in die EvTom gnostiese trekke. Maar hoe gnosties is die EvTom? Kloppenborg antwoord soos volg: alhoewel die EvTom nie die komplekse mitologiese raamwerk van die ontwikkelde gnostiek bevat nie, is die EvTom in die algemeen gnosties georienteerd. Die EvTom is egter ook ongetwyfeld 'n dokument wat tipies is van die laat-Joodse wysheidsliteratuur. Waar die EvTom, met sy anti-kosmiese inslag, dus duidelik na die gnostiek neig, daar neig dit ook na die Joodse wysheidstradisie wat die klem laat val op kennis as gevolg van insig in die menslike 
toestand. Die EvTom is dus gnosties in dié sin dat dit klem lê op selfverstaan as die sleutel tot verlossing, maar dit is egter ook tipies van die laat-Joodse wysheidstradisie wat leer dat selfverstaan alleen moontlik is deur die korrekte hoor en verstaan van Jesus se 'spreuke van wysheid' (kyk Kloppenborg et al 1990:98-99).

\section{HET TOMASNAVORSING ENIGE WAARDE VIR DIE TEOLOGIE VAN DIE KERK?}

Die vraag kan met reg gevra word of die bestudering van die EvTom, as nie-kanonieke evangelie, enige waarde vir die kerklike teologie inhou. Op hierdie vraag kan net instemmend geantwoord word, en die volgende opmerkings kan dien as illustrasie daarvan:

* Indien die EvTom beskou word as 'n volledig gnostiese produk van die tweede eeu, afhanklik van die Sinoptiese tradisie, kan die EvTom se tipering van Jesus en spiritualiteit een kant toe geskuif word as latere onortodokse afwykings van die kanon. By implikasie sal dit dan ook nie nodig wees om die kanon se eskatologies georienteerde beeld van Jesus en die wortels en oorsprong van die Christelike godsdiens te bevraagteken nie. Indien die standpunt egter ingeneem word dat die EvTom 'n onafhanklike, baie vroeë en unieke getuienis van die Jesustradisie verteenwoordig wat parallel, en in kompetisie met, die kanon onstaan het, moet die EvTom se verstaan van Jesus en spiritualiteit gesien word as 'n belangrike bron van getuienis rakende die ontstaan en wortels van die vroeë Christendom. En in so 'n ondersoek, druk Riley (1994:232) dit raak uit, is 'the theological stakes ... high'. In hierdie opsig sal daar byvoorbeeld aanpassings gemaak moet word wat betref die kanon se eskatologiese beskouings van Jesus, sowel as die kanon se eskatologieșe beskouings van die oorsprong van die Christelike kerk. Ook ons verstaan van die ontstaan, wording en opskrifstelling van die kanonieke evangelies sal die konsekwensies van laasgenoemde standpunt nie kan vryspring nie: indien die EvTom gesien word as afhanklik van die Sinoptiese tradisie kan die verskille tussen die logia in die sinoptiese evangelies en dié in die EvTom verklaar word in terme van redaksionele verwerkings; indien die tradisies in die EvTom egter vroëer is as dié in die kanonieke evangelies, kan geen studie van die Sinoptiese tradisies in die kanon die EvTom se weergawe van dieselfde tradisies verontagsaam nie (kyk Blomberg 1985:196; Riley 1994:232-233; Fallon \& Cameron 1988:4237; Kloppenborg et al 1990:103). 
* Die ontdekking van die EvTom bevestig weer eens die feit dat ons nie langer oor die vroeë Christendom (soos die Judaïsme) kan dink as in terme van diversiteit nie. Die EvTom, wat byvoorbeeld geen kruisteologie of getuienis van die opstanding van Jesus bevat nie, is weer eens bevestiging daarvan dat in die vroeë kerk onder die volgelinge van Jesus verskillende opinies was oor wie Jesus was, asook watter betekenis aan sy lewe en dood toegeken behoort te word. Natuurlik is dit so dat die afwesigheid van ' $n$ kruis- en opstandingsteologie in die EvTom toegeskryf kan word aan die genre van die EvTom as 'n 'sayings gospel'. Daar kan egter nie ontken word dat reeds in die kanon self verskil van opinie is wat hierdie sake betref nie (kyk Kloppenborg et al 1990:77).

* Omdat daar geen teks van die Q-bron bestaan nie, is navorsers van Matteus en Lukas (met uitgangspunt die prioriteit van Markus) afhanklik om $Q$ te konstrueer. Onlangse navorsing op Q (bv Klopenborg \& Mack) het byvoorbeeld aangetoon dat $\mathrm{Q}$ (soos dit vanuit Matteus en Lukas gekonstrueer kan word) heel waarskynlik 'n aantal redaksionele verwerkings ondergaan het: die vroegste laag van $Q$ tipeer Jesus as 'n wysheidsleraar, terwyl latere stadiums van ontwikkeling in $Q$ Jesus skets as die Goddelike Seun van die Mens. $Q$ is dus, volgens hierdie konstruksie, 'n dokument wat in sy vroegste laag Jesus nie sien as 'n apokaliptiese figuur met 'n daarmee gepaargaande kruisteologie nie. Genoemde literêre lae in $Q$, en selfs die moontlike bestaan van so ' $n$ dokument is egter al in verskeie studies (bv dié van Farmer) bevraagteken. Die ontdekking van EvTom het egter empiries bevestig dat die vroeë Christene nie alleen Jesus-logia in bepaalde versamelings versamel het nie, maar ook dat dokumente wat Jesus nie tipeer as 'n apokaliptiese figur en gekruisigde verlosser nie, bestaan. Die ontdekking van die EvTom 'thus provided important corroboration for the view that both Matthew and Luke did utilize Q' (Mack, in Riley 1994:237), en dat dokumente soos Q wel bestaan het (kyk Riley 1994:237; Kloppenborg et al 190:105).

* Die ontdekking van die EvTom werp volgens Nuwe-Testamentici soos Davies en Patterson lig op die opponente van Paulus in 1 Korintiërs, en kan ook met vrug gebruik word om die teologie van die Johannesevangelie te bestudeer (kyk Riley 1994:240). Vir beide die EvTom en die Johannesevangelie, as voorbeeld, is die hoor en verstaan van die woorde van Jesus die sleutel tot verlossing (Kloppenborg et al 1990:107). 
* Wat betref die studie van die gelykenisse van Jesus verifieer die EvTom die teorie dat die allegorisering van die gelykenisse in die kanonieke evangelies gesien moet word as latere ontwikkelings van die tradisie en dus as gemeenteteologie. Die EvTom is dus ' $n$ ryk veld om die gelykenistradisie in sy meer oorspronklike stadium te ondersoek (kyk Kloppenborg et al 1990:103).

* Die ontdekking van die EvTom is verder van groot hulp vir ons verstaan van die ontwikkeling en oordrag van die tradisies rondom Jesus. Die EvTom toon byvoorbeeld aan hoe maklik dit vir sommige groepe onder die eerste volgelinge van Jesus was om tradisies met 'n wysheidsinslag te omvorm tot 'n gnostiese verstaan daarvan. Hierdie soort van omvorming mag heel waarskynlik ook die rede wees waarom geen versameling van Jesus-logia, in die vorm van 'n 'sayings collection', kon oorleef in meer ortodokse Christelike kringe nie. Die EvTom se gnostiese tendens het heel moontlik suspisie laat onstaan wat betref alle versamelings van Jesus-logia. Deur egter verskillende logia van Jesus in die narratiewe struktuur van die Evangelies op te neem, is dié tendens nie alleen teengewerk nie, maar is dit ook waarskynlik die rede hoekom $Q$ net oorleef het in terme van opname in die kanonieke Matteus en Lukasevangelies (kyk Kloppenborg et al 1990:104).

* Wat betref die EvTom en die jongste navorsing rakende die historiese Jesus, stip Kloppenborg et al (1990:114-120) die volgende sake aan in terme waarvan die EvTom van groot waarde is vir historiese Jesus-navorsing: wat betref die aantoon van bepaalde logia as sou dit uit die mond van Jesus kom of nie, is die EvTom 'n baie belangrike bron in terme van meerdere attestasie. Tweedens het die ontdekking van die EvTom in 'n baie groot mate die korpus van tradisies vergroot wat na Jesus teruggevoer word. Drie gelykenisse wat heel waarskynlik na Jesus teruggevoer kan word, te wete EvTom 21 (die gelykenis van die kinders), EvTom 97 (die gelykenis van die vroue) en EvTom 98 (die gelykenis van die sluipmoordenaar) kom net in die EvTom voor. Laastens is dit duidelik dat vir Tomas die belang van Jesus was dat, wanneer Hy gepraat het, die koninkryk van God vir die mense wat Hom gehoor en verstaan het 'n teenswoordige realiteit geword het. In terme van die navorsing oor die historiese Jesus dring hierdie tipering van Jesus deur die EvTom, aldus Kloppenborg, die volgende belangrike vraag na vore: wat het Tomas se Jesus in gemeen met die historiese Jesus? Miskien niks, miskien alles. 


\section{Endnote}

1 Die aantal boeke en artikels wat gewy word aan die studie van die Tomasevangelie het in 1985 reeds 600 oorskry (Riley 1994:227). 'n Vinnige deurlees van die literatuurlyste in die navorsingsberigte van Fallon \& Cameron (1988), Patterson (1992) en Riley (1994) toon aan dat die aantal boeke en artikels wat handel oor die Tomasevangelie teen 1994 reeds ten minste 800 oorskry het.

2 Hierdie manuskripte, komende uit die biblioteek van een van die ou kloosters in Egipte, is heel waarskynlik teen ongeveer $370 \mathrm{n} \mathrm{C}$ begrawe nadat die aartsbiskop van Aleksandrië alle Christene opdrag gegee het om boeke soos die Tomasevangelie (met 'n gnostiese oriëntasie) te verbrand, aangesien dit volgens hom ketterye verkondig het (kyk Pagels 1995:69-70).

3 Vir 'n meer breedvoerige bespreking van die ontdekking by Nag Hammadi, asook Doresse se 'tweede ontdekking' daarvan, kyk Doresse (1960) en Robinson (1979a:206-224; 1979b:239-248). Kyk ook Pagels (1990:13-16) wat van mening is dat die ontdekking te Nag Hammadi deur Muhammed 'Ali al-Samman die gevolg was van 'n bloedmoord op Ahmed Ismail om sy vader se dood te wreek, en dat dit die hoofrede was waarom Muhammed 'Ali al-Samman nie onmiddellik sy vonds op die oudhede mark geplaas het nie.

4 Kopties is die laatste vorm van die oorspronklike antieke Egiptiese skrif. Voor die periode van Christelike evangelisering in Egipte was die skrif wat gebruik was, die bekende hiëroglifiese skrif, of dan die hiëratiese of demotiese skrif, die kursiewe vorm van die hiëroglifiese skrif. In die tweede eeu, toe die Christelike sending vanuit Aleksandrië op die plattelandse gebiede in Egipte begin konsentreer het, het die sendelinge verkies om hulle tekste in Egipties te vertaal, deur gebruik te maak van Griekse simbole, eerder as byvoorbeeld die oorspronklike demotiese skrif. Die Koptiese teks van die Tomasevangelie is daarom heel waarskynlik ' $n$ vertaling van 'n oorspronklike Griekse weergawe daarvan (Kloppenborg et al 1990:81-82).

5 In wese is EvTom ook nog vroeër as 1897 'ontdek', aangesien daar in geskrifte van kerkvaders van die tweede eeu soos Hippolytus (in sy Ad. Haer. 5.7.20) en Eusebius (in sy Hist. Eccl. 3.25.6) verwysings na die EvTom is (kyk Riley 1994:227).

6 Interessant is dat Grenfell \& Hunt reeds in 1897 gesuggereer het dat P Oxy 1 heel waarskynlik 'n fragment is van 'n versameling van Jesus-logia wat nie geneem is uit ' $n$ narratiewe evangelie nie, dat hierdie logia van Jesus nie noodwendig ketters of gnosties nie, dat die versameling Jesuslogia waaruit P Oxy 1 kom aan die einde eerste begin tweede eeu sy ontstaan het, en dat dit moontlik is dat ons hier met ' $n$ ander tradisie te make het as dié waarvan die kanonieke evangelies gebruik gemaak het (Fallon \& Cameron 1988:4224-4225).

7 Dit is belangrik om daarop te let dat die Griekse en Koptiese tekse in hierdie verband nie dieselfde is nie. In sommige gevalle is daar redelike groot verskille: P Oxy 130 (= EvTom 30), bestaan byvoorbeeld uit EvTom 30 en EvTom 77:2-3. Dit is dus duidelik dat daar ten minste twee Koptiese weergawes van die vroeëre Griekse teks was (kyk Pallon \& Cameron 1988:4202; kyk ook Mueller 1973:266-276). Attridge toon verder aan dat hierdie 3 fragmente ons nie toelaat 
om te bepaal of hulle mekaar oorgeskryf het, of almal uit dieselfde bron oorgeskryf het, of dat hulle aparte resensies van EvTom verteenwoordig nie. Nadat die Koptiese vertaling gepubliseer is, het veral Fitzmeyer, Hofius, Kraft en Marcovich gepoog om die lakunes in die Griekse fragmente te herstel (kyk Fallon \& Cameron 1988:4202). Marcovich is byvoorbeeld van mening dat, op grond van sy gepostuleerde Griekse teks, P Oxy 1, 654 en 655 vanuit dieselfde Griekse teks oorgeskryf is. Sy teorie word egter myns insiens oortuigend deur Attridge afgewys (kyk Fallon \& Cameron 1988:4202).

8 Vir die verskille tussen die Koptiese teks van die EvTom en die Griekse framente in P Oxy 1, 654 en 655, kyk Fallon \& Cameron (1988:4203), Kloppenborg et al (1990:101-134), Patterson (1993:18-94) en Funk et al (1993:471-495).

9 Verskeie redes word aangevoer waarom dit so lank geneem het voordat die publikasie van die tekste uit die Nag Hammadi biblioteek die lig gesien het. Volgens Kloppenborg et al (1990:82) was van die redes onder andere die politieke klimaat in Egipte na 1945 (bv die krisis rondom die Zuezkanaal), asook 'smaller political struggles for scholarly turf, and attempts to monopolize access and publication rights to the exciting new texts' (Kloppenborg et al 1990:82). Pagels (1990) meen egter dat daar ander redes vir hierdie vertraging was: die feit dat die EvTom, as Christelike dokument, gnosties georienteerd is, dat dit nie die liggaamlike opstanding van Jesus leer nie, dat dit die institusionele hiërargie in die kerk bevraagteken, dat dit 'n besondere plek aan vroue in die kerk toeken, en in die besonder daarop dui dat die Christelike kerk se wortels moontlik in die gnostiek lê, was daarvoor verantwoordelik dat die EvTom as nuutontdekte teks nie onmiddellik gepubliseer is nie.

10 Vir ander publikasies en vertalings van die Koptiese EvTom wat tussen 1959 en 1988 verskyn het, byvoorbeeld die publikasies van Doresse (1959; die eerste teks van die EvTom waar die Koptiese teks met Nuwe-Testamentiese paralelle vergelyk word); Schippers (1960; sy Duitse vertaling); die monograaf van Haenchen (1960; sy vertaling is opgeneem in die bekende Synopsis Quattuor Evangeliorum), Kasser se monograaf (1961; bestaande uit 'n vertaling en 'n Griekse retroversie van die Koptiese teks); die vertalings van Houghton (1963), Schmidt (1966), Summers (1986), Cartlidge (1968; later deur Davies (1983) gebruik vir sy Tomasboek); en die van Suarez (1974) en Meyer (1992), kyk Fallon \& Cameron (1988:4197-4200) en Riley (1994:228).

11 Die vraag is of Grant nie hier die Traditionsgeschichte (die bestudering van o a mondelinge tradisies) met die Formgeschichte (die bestudering van o a die skriftelike fiksering van mondelinge tradisies a $\mathrm{g} v$ ' $\mathrm{n}$ bepaalde Sitz im Leben) verwar nie. Wanneer daar in ag geneem word dat 'n spesifieke Sitz im Leben tog op een of ander manier aanleiding moes gegee het tot die totstandkoming van die EvTom, is die Formgeschichte wel bruikbaar in 'n studie soos die van Grant.

12 Daar is veertien gelykenisse in EvTom (waarvan elf parallelle in die evangelies het) en drie Tomas-Sondergut is: EvTom 9 (die gelykenis van die saaier), EvTom 20 (die gelykenis van die mosterdsaad) en EvTom 65 (die gelykenis van die bose huurders) het parallelle in Markus, Matteus en Lukas; EvTom 64 (die gelykenis van die groot maaltyd), EvTom 96 (die gelykenis van die suurdeeg) en EvTom 107 (die gelykenis van die verlore skaap) het parallelle in Matteus en Lukas; 
EvTom 8 (die gelykenis van die visserman), EvTom 57 (die gelykenis van die onkruid), EvTom 76 (die gelykenis van die kosbare pêrel) en EvTom 109 (die gelykenis van die skat) het parallelle in Matteus; EvTom 63 (die gelykenis van die ryk boer) het 'n parallel in Lukas; en EvTom 21 (die gelykenis van die kinders), EvTom 97 (die gelykenis van die vroue) en EvTom 98 (die gelykenis van die sluipmoordenaar) kom net in die EvTom voor.

13 Met enkratitiese teologie bedoel Quispel, in soverre die afleiding korrek is, 'n teologie wat klem lê op selfbeheersing en die afsondering van die liggaam ( $\mathrm{d} w \mathrm{~s}$ asketisme).

14 Crossan aanvaar Patterson se datering van 62 n C ten opsigte van die EvTom, 'n datering wat 'n baie groot rol speel in Crossan se konstruksie van die historiese Jesus.

15 Verskeie navorsers is van mening dat die vraag of die EvTom gnosties is of nie 'n rol behoort te speel in die datering van die EvTom. Koester \& Patterson (kyk Riley 1994:230) het egter cortuigend aangetoon dat die gnostiek as godsdientige oriëntasie nie sy onstaan eers in die tweede eeu gehad het soos baie navorsers beweer nie, maar so vroeg as die Christendom self is. Om hierdie rede word hierdie aspek in die bespreking van die datering van die EvTom nie hier hanteer nie. Wat betref die moontlike plek van skrywe van die EvTom laat die omvang van die onderhawige artikel nie toe dat daaraan volledig aandag gegee kan word nie. Kortliks kan hier vermeld word dat navorsers Sirië (in die besonder Edessa) of Egipte sien as die waarskynlikste plekke van skrywe van die EvTom.

16 'n Onlangse ontdekte fragment bestaande uit 'n gedeelte van 'n brief van Klemens van Aleksandrië (ca 150-215 n C) bevat byvoorbeeld 'n aanhaling uit Markus wat nie in die huidige Markusteks voorkom nie. Dit dui daarop dat antieke tekste soos Markus soms uitgebrei en ander kere weer ingekort is.

17 In hierdie verband maak Mees die interessante opmerking dat, aangesien die EvTom uit 'n versameling Jesus-logia bestaan sonder 'n narratiewe struktuur wat hierdie logia saambind, die teenwoordigheid van verhalende gnostiese mites nie in EvTom sal voorkom nie. Syns insiens is Quispel se argument - dat daar in die EvTom nie 'n ontwikkelde mitologie voorkom nie en die EvTom dus nie gnosties kan wees nie - daarom nie geldig nie. Indien mites soos dié sou voorkom, sou dit ook nie inskakel by die res van die struktuur van die teks nie en uit pas wees met die algemene teorie ten opsigte van die ontwikkeling van antieke tekste (Fallon \& Cameron 1988:4231).

18 In verband met EvTom 28 argumenteer Richardson dat 'the richness of myth cannot be seen as a decisive test for Gnosticism ... the question of whether the world is regarded as essentially evil is far more important' (Richardson, in Fallon \& Cameron 1988:4231). Volgens Richardson is EvTom 28:1 ( $=$ P Oxy $128: 1$ ), in teenstelling met Quispel se verstaan daarvan, dus eerder 'n teken van die EvTom se gnostiese trekke, in die sin dat die кó $\mu_{\mu \circ}$ (in EvTom 28:1) as negatief

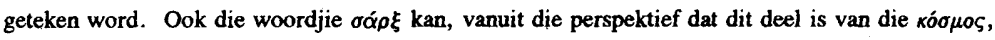
negatief (gnosties) geïnterpreteer word. 
19 Klijn se ondersoek na die Edesseense Christendom het egter aangetoon dat Quispel nie korrek is wanneer hy kategories verklaar dat daar geen getuienis is van gnostici wat in die kerke in die omgewing van Edessa aktief was nie (kyk Fallon \& Cameron 1988:421).

20 Quispel vind ondersteuning vir sy argumente veral by Englezakis en Ménard. Volgens Englezakis is die teologie van die EvTom duidelik enkratities, veral as die gebruik van $\mu$ ovoxó $\zeta$ in EvTom 30 (= P Oxy 130 ) in ag geneem word, 'n term wat volgens Englezakis die EvTom duidelik in 'n 'non-gnostic, ascetico-encratite milieu' plaas (kyk Riley 1994:229).

21 Die vraag is natuurlik of Davies sal kan aantoon dat al die logia in die EvTom met die doop of 'n bepaalde dooppraktyk in die vroee kerk te make het. Sy standpunt dat te veel navorsers net eenvoudig aanvaar dat die EvTom gnosties is, maar nie substansiële gronde daarvoor aanbied nie, geld ook vir sy eie standpunt, te wete dat daar geen 'meaningful' of 'nuanced' gnostiek in die EvTom voorkom nie, aangesien ook Davies vir hierdie uitspraak geen substansiële argumente op die tafel plaas nie (kyk ook Fallon \& Cameron 1988:4231).

\section{Literatuurverwysings}

Blomberg, C L 1985. Tradition and redaction in the parables of the Gospel of Thomas, in Wenham, D (ed), The Jesus tradition outside the gospels, 177-205. Sheffield: JSOT Press. (Gospel perspectives 5).

Davies, S L 1983. The gospel of Thomas and Christian wisdom. New York: Seabury.

Dehandschutter, B 1992. Recent research on the gospel of Thomas, in Segbroeck, F (ed), The four Gospels, 2257-2262. Leuven: University Press.

Dodd, C H 1961. The parables of the kingdom. New York: Scribner's.

Doresse, J 1960. The secret books of the Egyptian gnostics: An introduction to the gnostic coptic manuscripts discovered at Chenoboskion. New York: Viking.

Fallon, F T \& Cameron, R 1988. The gospel of Thomas: A Forschungsbericht and analysis. $A N R W 2.25 .6,4195-4251$.

Funk, W, Hoover, R W and the Jesus Seminar 1993. The five gospels: The search for the authentic words of Jesus. New York: Polebridge Press.

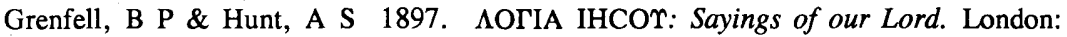
Frowde.

- 1904. New sayings of Jesus and fragment of a lost gospel from Oxyrhynchus. London: Frowde.

Guillaumont, A et al 1959. The gospel according to Thomas: Coptic text established and translated. Leiden: Brill.

Jeremias, J 1972. The parables of Jesus. New York: Scribner's.

Kloppenborg, J S, Meyer, M W, Patterson, S J \& Steinhauser, M G 1990. Q Thomas reader. Sonoma: Polebridge Press. 
Koester, H 1990. Ancient Christian gospels: Their history and development. Philadelphia: Trinity Press International.

Layton, B 1989. Introduction to the gospel of Thomas, NHC II.2, in Layton, B (ed), Nag Hammadi Codex II. 2-7, 172-195. Leiden: Brill. (Nag Hammadi Studies 20.)

Leipoldt, J 1967. Das Evangelium nach Thomas: Koptisch und Deutsch. Berlin: Akademie-Verlag. (TU 101.)

Meyer, M 1992. The Gospel of Thomas: The hidden sayings of Jesus. San Francisco: Harper.

Mueller, D 1973. Kingdom of heaven or kingdom of God. VC 27, 266-276.

Pagels, E 1990. The gnostic gospels. London: Penquin Books.

1995. The origin of Satan. London: Penquin Books.

Patterson, S J 1992. The gospel of Thomas and the synoptic tradition: A Forschungsbericht and critique. Foundations and Facets Forum 8, 1-54.

1993. The gospel of Thomas and Jesus. Sonoma: Polebridge Press.

Riley, G J 1994. The Gospel of Thomas in recent scholarship. Currents in Research 2, 227-252.

Robinson, J M 1979a. The discovery of the Nag Hammadi codices. Biblical Archeologist 42, 206-224.

1979b. Getting the Nag Hammadi library into English. Biblical Archeologist 42, 239-248.

Robinson, J M \& Koester, H 1971. Trajectories through early Christianity. Philadelphia: Fortress Press. 